\title{
FUNCTIONAL DISORDERS OF THE TEMPOROMANDIBULAR JOINTS AS A FACTOR RESPONSIBLE FOR SLEEP APNOEA
}

\section{ZABURZENIA CZYNNOŚCIOWE STAWÓW SKRONIOWO-ŻUCHWOWYCH JAKO CZYNNIK POWSTAWANIA BEZDECHU NOCNEGO*}

\author{
Katedra i Zakład Protetyki Stomatologicznej Pomorskiego Uniwersytetu Medycznego w Szczecinie \\ ul. Powstańców Wlkp. 72, 70-111 Szczecin \\ Kierownik: prof. dr. hab. n. med. Bogumiła Fraczak \\ ${ }^{1}$ Zakład Anatomii Prawidłowej i Klinicznej Pomorskiego Uniwersytetu Medycznego w Szczecinie \\ ul. Powstańców Wlkp. 72, 70-111 Szczecin \\ Kierownik: dr. hab. n. med. Zbigniew Ziętek \\ ${ }^{2}$ Klinika Medycyny Ratunkowej i Obrażeń Wielonarządowych Collegium Medicum Uniwersytetu Jagiellońskiego w Krakowie \\ ul. Kopernika 21, 31-501 Kraków \\ Kierownik: dr hab. med. Leszek Brongel
}

\section{Streszczenie}

Wstęp: Zaburzenia czynnościowe stawów skroniowo-żuchwowych (ssż) we współczesnej populacji uznawane są przez Światową Organizację Zdrowia za trzecią pod względem częstotliwości występowania w stomatologii chorobę po próchnicy i peridontologii. Uważa się, że dotyczą $84 \%$ dorosłej populacji. Natomiast u osób po 65 . r.ż. zaburzenia te nasilają się i mogą dotyczyć nawet $100 \%$ populacji w tym przedziale wiekowym.

Materiat i metoda: Przebadano 150 pacjentów w wieku 35-70 lat (średnia wieku 46,5). Wszyscy byli diagnozowani w latach 2006-2010 w Katedrze i Zakładzie Protetyki Stomatologicznej Pomorskiego Uniwersytetu Medycznego w Szczecinie z powodu podejrzenia występowania mniej lub bardziej zaawansowanej postaci zaburzeń czynnościowych układu stomatoganatycznego, a szczególnie ssż. Stopień zaawansowania zaburzeń określono za pomocą wskaźnika Helkimo.

Wyniki: U 112 pacjentów zdiagnozowano zaburzenia czynnościowe ssż oraz stwierdzono występowanie wczesnych postaci bezdechów nocnych. Na podstawie uzyskanych wyników badań stwierdzono, że stopień zaawansowania postaci bezdechów nocnych był wprost proporcjonalny do czasu trwania i ciężkości dysfunkcji ssż.

Wniosek: Większość pacjentów nie łączyła objawów bezdechów nocnych z nieprawidłowościami układu stomatognatycznego.

H a s ła: układ stomatognatyczny - staw skroniowo-żuchwowy - zaburzenia czynnościowe - bezdech nocny.

\section{Summary}

Introduction: Functional disorders of the temporomandibular joints (TMJ) in the contemporary population are considered by World Health Organization to be the third most frequent dental disease after caries and periodontitis. It is thought to affect $84 \%$ of the adult population. In patients aged 65 years and older these disorders become more severe and may affect up to $100 \%$ of this age group.

Material and method: We examined 150 patients aged 35-70 years (mean age 46.5 years). All patients were diagnosed in 2006-2010 at the Department of Dental Prosthetics

\footnotetext{
* Praca wygłoszona podczas „International Conference Advances in Pneumology”, Wrocław, 5-6.10.2012 r.
} 
of the Pomeranian Medical University in Szczecin due to suspected more or less advanced functional disorders of the stomatognathic system, particularly TMJ. The severity of the disorders was identified using the Helkimo index.

Results: Functional disorders of the TMJ and mild sleep apnoea were diagnosed in 112 patients. Findings from the study indicated that the severity of sleep apnoea was positively correlated with the duration and severity of TMD.

Conclusion: Most patients did not link the symptoms of sleep apnoea with dysfunctions of the stomatognathic system.

K e y w o r d s: stomatognathic system - temporomandibular joint - functional disorders - sleep apnoea.

\section{Introduction}

The stomatognathic system is an anatomical structure formed by the muscles and bones of the head, neck and shoulder girdle, closely linked in terms of their functionality and morphology. Anatomically, it includes the mandibular bone, maxilla with dental alveoli and teeth, temporomandibular joints, symmetrical contact points, the system of nerves and muscles, blood and lymph vessels and secretory glands. This anatomical system, like any other part of the human body, is affected by physiological changes. Being morphologically and functionally integrated, it also undergoes dynamic changes during life $[1,2,3]$. The stomatognathic system in young people with unfinished development of the masticatory organ differs from that in adults $[4,5]$. Degenerative changes also occur due to ageing and wear of individual elements of this system $[6,7,8]$. Structural and functional changes depend on ageing of the body, but are also determined by emotional and mental factors [4]. Epidemiological studies demonstrated a gradual increase in the incidence of functional disorders of the stomatognathic system. This process is attributed to both general local and environmental causative factors, such as exposure to specific working environment or living conditions. Local factors include para- or dysfunctions in the dynamics of the masticatory organ, loss of dentition in the support zones, bone atrophy in the facial skeleton, or iatrogenic injury. Due to the multifactorial nature and diversified clinical manifestations, dysfunctions of the stomatognathic system and its elements are a significant diagnostic and therapeutic problem $[6,8,9]$.

Temporomandibular disorders (TMD), particularly those of a functional nature, have recently become an increasingly frequent reason for patients' visits to dentists. Statistical data indicate that $84 \%$ of the adult population suffer from symptoms of differing severity of TMD [9]. Functional disorders are manifested by clicking or popping sounds, luxation, muscle pain and other symptoms $[1,2,6,7,9,10,11]$. In a targeted interview patients from this group, especially those with severe functional disorders of the temporomandibular joints (TMJ), also reported sleep apnoea of differing severity. In most cases, sleep apnoea was manifested by snoring. These symptoms are usually observed in patients lacking teeth in the alar region of the mandible, but also in completely edentulous patients using the same removable prosthetic restoration for many years $[1,12,13,14]$.

The aim of this study was to analyse the correlation between the incidence of functional TMD and sleep apnoea.

\section{Material and method}

We initially examined 150 patients diagnosed at the Department of Dental Prosthetics of the Pomeranian Medical University of Szczecin due to the suspected advanced functional disorders of the stomatognathic system. Of these, 38 were referred for further differential diagnosis to other doctors, including laryngologists and orthopaedic specialists. The remaining 112 patients were diagnosed with functional disorders of the stomatognathic system. The severity of functional disorders was identified using the Helkimo index.

The patients were classified into 3 groups. Group A comprised patients with minor dysfunctions $(\mathrm{n}=36 ; 31 \mathrm{~F}, 5 \mathrm{M}$; age 35-42 years). Group B comprised patients with moderate dysfunctions ( $\mathrm{n}=54 ; 47 \mathrm{~F}, 7 \mathrm{M}$; age 35-55 years), and group $\mathrm{C}$ comprised patients with severe dysfunctions $(\mathrm{n}=22$; 18 F, 4 M; age 54-70 years) - tables 1 and 2.

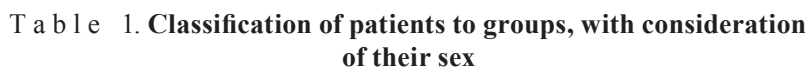

T a b l e 1. Classification of patients to groups, with consideration of their sex

\begin{tabular}{lcc}
\multicolumn{1}{c}{ Study group } & Female & Male \\
\hline Group A & $31(81 \%)$ & $5(19 \%)$ \\
\hline Group B & $47(87 \%)$ & $7(13 \%)$ \\
\hline Group C & $17(77 \%)$ & $5(23 \%)$ \\
\hline Total & $95(85 \%)$ & $17(15 \%)$ \\
\hline
\end{tabular}

$\mathrm{T}$ a b $1 \mathrm{e}$ 2. Classification of patients by age

\begin{tabular}{lccc} 
Study group & $35-45$ & $46-55$ & $>70$ years \\
\hline Group A & 36 & - & - \\
\hline Group B & 10 & 44 & - \\
\hline Group C & - & 18 & 4 \\
\hline Total & $46(41 \%)$ & $62(55 \%)$ & $4(4 \%)$ \\
\hline
\end{tabular}

A standard dental examination, including classification acc. to the Helkimo index, was carried out in all patients. We identified the range, symmetry and trajectory of the posterior, anterior and lateral mobility of the mandible. We assessed the condition of masseter muscles, including the tone, pain symptoms and sensitivity to pressure, using the VAS scale. The examination was also focused on concomitant acoustic symptoms, such as clicking or popping sounds in the TMJ during movement of the mandible. We analysed panoramic 
radiographs taken for patients, and in selected cases also functional temporomandibular radiograms. We identified edentulism acc. to the Eichner index, and the duration of use and quality of removable dental restorations (partial or complete). All patients were referred to a laryngologist for consultation to rule out malformations and diseases that could potentially be responsible for breathing disorders. A targeted questionnaire-based interview was carried out in all patients, and this included questions on the patient's knowledge of the presence and severity of sleep apnoea.

Patients were asked the following questions:

1. Do you have frequent problems with falling asleep?

2. Do you wake up too early in the morning?

3. Do you wake up at night and if so, do you have problems with falling asleep after that?

4. Do you often feel tired after waking up in the morning?

5. Have your relatives told you that you snore?

6. How long have you been snoring -1 month, 3 months, 6 months, longer than 6 months

7. Do you know of any medications which reduce snoring?

To analyse the correlation between the individual variables presented in contingency tables, we carried out $\chi^{2}$ independence tests. We tested a zero hypothesis, that variables in the table are independent, and an alternative hypothesis on the correlation between the variables. We calculated the values of the verification score for $\chi^{2}$ and critical values of $\chi_{\alpha}^{2}$ distribution for the adopted critical significance level $\alpha=0.05$. For $\chi^{2}<\chi_{\alpha}^{2}$ there was no reason to reject the hypothesis on the independence of variables, and for $\chi^{2} \geq \chi_{\alpha}^{2}$ the hypothesis on independence was rejected in favour of the alternative hypothesis.

\section{Summary of results}

About $59 \%$ of the diagnosed patients were older than 45 years. Dysfunctions grup B i C of the TMJ various severity were diagnosed in over $68 \%$ of patients acc. to Helkimo index. Changes in the position of the mandible against the maxilla caused by the loss of support zones in the alar region were found. Over $50 \%$ of patients were lacking teeth in the alar region or were completely edentulous (Tabs. 1-4). Most patients (75.1\%) had removable prosthetic restorations that were older than 5 years (Tabs. 5 and 6). In the targeted interview more than $50 \%$ of positive answers were obtained from patients in groups $\mathrm{B}$ and $\mathrm{C}$, which confirmed the presence of symptoms such as sleep disorders and sleep apnoea. The analysed patients had no knowledge of medications or management strategies for sleep apnoea (Tab. 7).

Statistical analysis demonstrated that individual groups of patients differed in terms of age, severity of dysfunction measured by the Helkimo index, edentulism measured by the Eichner index, and the type of removable partial or total prosthetic restoration (Tabs. 1 and 2). However, no differences between patients were found in terms of sex and the
$\mathrm{T}$ a b $1 \mathrm{e}$ 3. Classification of patients by the severity of dysfunction acc. to Helkimo index

\begin{tabular}{lccc}
\multicolumn{1}{c}{ Study group } & Helkimo I & Helkimo II & Helkimo III \\
\hline Group A & 36 & - & - \\
\hline Group B & - & 54 & - \\
\hline Group C & - & - & 22 \\
\hline Total & $36(32 \%)$ & $54(48 \%)$ & $22(20 \%)$ \\
\hline
\end{tabular}

T a b l e 4. Classification of patients acc. to the Eichner index for partial or total edentulism

\begin{tabular}{lccc} 
Study group & $\begin{array}{c}\text { Class } \\
\text { B2 and B3 }\end{array}$ & $\begin{array}{c}\text { Class } \\
\text { B3 and B4 }\end{array}$ & $\begin{array}{c}\text { Class } \\
\text { C1, C2, C3 }\end{array}$ \\
\hline Group A & 20 & 16 & - \\
\hline Group B & 30 & 24 & - \\
\hline Group C & 2 & 11 & 9 \\
\hline Total & $52(46.4 \%)$ & $51(45.5 \%)$ & $9(8.1 \%)$ \\
\hline
\end{tabular}

$\mathrm{T}$ a b $1 \mathrm{e}$ 5. Classification of to the type permanent restoration, removable restoration, non restoration or restoration incorrect

\begin{tabular}{lccc} 
Study group & $\begin{array}{c}\text { Permanent } \\
\text { restoration }\end{array}$ & $\begin{array}{c}\text { Removable } \\
\text { restoration }\end{array}$ & $\begin{array}{c}\text { Non restoration } \\
\text { or restoration } \\
\text { incorrect }\end{array}$ \\
\hline Group A & 30 & 1 & 5 \\
\hline Group B & 7 & 20 & 27 \\
\hline Group C & 2 & 15 & 5 \\
\hline Total & $39(34.82 \%)$ & $36(32.14 \%)$ & $37(33.04 \%)$ \\
\hline
\end{tabular}

$\mathrm{T}$ a b $1 \mathrm{e}$ 6. Classification of patients acc. to duration of use of removable partial or total prosthetic restoration

\begin{tabular}{lccc}
$\begin{array}{c}\text { Use of prosthetic } \\
\text { restorations }\end{array}$ & $\begin{array}{c}1-2 \text { years } \\
\%\end{array}$ & $\begin{array}{c}3-5 \text { years } \\
\%\end{array}$ & $\begin{array}{c}>5 \text { years } \\
\%\end{array}$ \\
\hline Group A & 2 & 2 & 8 \\
\hline Group B & 2 & 5 & 17 \\
\hline Group C & - & - & 5 \\
\hline Total & $4(9 \%)$ & $7(15.9 \%)$ & $30(75.1 \%)$ \\
\hline
\end{tabular}

$\mathrm{T} \mathrm{a} \mathrm{b} 1 \mathrm{e}$ 7. Results from the targeted questionnaire-based interview on self-reported breathing disorders

\begin{tabular}{cccc} 
Questions & $\begin{array}{c}\text { Group A } \\
\mathrm{n}=36 \\
\text { Yes/No }\end{array}$ & $\begin{array}{c}\text { Group B } \\
\mathrm{n}=54 \\
\text { Yes/No }\end{array}$ & $\begin{array}{c}\text { Group C } \\
\mathrm{n}=22 \\
\text { Yes/No }\end{array}$ \\
\hline 1 & $16 / 20$ & $34 / 20$ & $20 / 2$ \\
\hline 2 & $15 / 21$ & $32 / 22$ & $18 / 4$ \\
\hline 3 & $14 / 22$ & $30 / 24$ & $20 / 2$ \\
\hline 4 & $15 / 21$ & $29 / 25$ & $17 / 5$ \\
\hline 5 & $30 / 6$ & $50 / 4$ & $22 / 0$ \\
\hline 6 & $<2$ months & $<4$ months & 6 months or longer \\
\hline 7 & $0 / 36$ & $0 / 54$ & $0 / 22$ \\
\hline
\end{tabular}

time for which removable partial or total prosthetic restorations were used (3-6). The answers of patients to questions $1-4$, regarding self-reported breathing disorders, differed in groups A, B and C. Answers to questions 1 to 4 were correlated with the study group, but not answers to question 5 . 
T a b l e 8. Results from the $\boldsymbol{\chi}^{2}$ independence test for questions on self-reported breathing disorders

\begin{tabular}{crcc} 
Questions & \multicolumn{1}{c}{$\chi^{2}$} & $\chi_{\alpha}^{2}$ & Test results \\
\hline 1 & 12.59 & 5.99 & zero hypothesis rejected \\
\hline 2 & 9.10 & 5.99 & zero hypothesis rejected \\
\hline 4 & 15.20 & 5.99 & zero hypothesis rejected \\
\hline 5 & 7.00 & 5.99 & zero hypothesis rejected \\
\hline
\end{tabular}

We were unable to carry out the $\chi^{2}$ independence test for scores from questions 6 and 7 , as they did not meet the test objectives (Tabs. 7 and 8).

\section{Discussion}

Temporomandibular joints are involved in important processes of human physiology, such as breathing, mastication, swallowing and speech. External respiration takes place in the airways, which in their upper part filtrate, warm and moisturize the inhaled air. Many people breathe through the mouth, which physiologically is not a part of the airways. Mouth breathing is a pathological process caused by impaired patency of the nose (curved septum, nasal polyps), diseases of paranasal sinuses, or malocclusion. In the early ontogenesis, mouth breathing contributes to the development of occlusal disorders (crossbite) and temporomandibular joint disorders, and disturbs speech articulation. Theories explaining developmental disorders in the anatomy of the stomatognathic system associated with mouth breathing indicate two factors: pressure and hypofunction [10]. Epidemiological studies demonstrated that over $80 \%$ of the adult population is affected by functional disorders of the TMJ, as also confirmed by our findings [2, 3, 4, 5]. Patients with breathing disorders caused by dysfunctions of the TMJ persistently inhale insufficient amounts of air, and are predisposed to obstructive sleep apnoea (OSA). As a consequence, they suffer from drowsiness during the daytime, and circulatory disorders, which may be associated with insufficient oxygen supply to the brain, heart, kidneys and liver. Treatment of functional disorders of the stomatognathic system is difficult due to the multifactorial aetiology of this disease. Thus, patients may present with symptoms of different severity $[3,5,12]$. The patients analysed in our study had similar symptoms to those reported in papers by DeBoever and Adriaens, and van der Meulen [1, 14]. The analysis of findings from a targeted questionnaire-based interview allowed us to identify patients' knowledge of the presence and severity of sleep apnoea. The obtained data are comparable to those reported by DeBoever and Adriaens, Marbach, and Michelotti et al. [1, 3, 4]. The study demonstrated that changes in the stomatognathic system caused by lowered occlusion, especially those resulting from incorrect prosthetic restoration or shortened dental arches, may be a factor responsible for functional disorders, and further lead to breathing disorders $[4,13]$. Snoring, however, may, but does not have to be, a symptom of developing sleep apnoea $[15,16,17,18]$.

\section{Conclusions}

1. The severity of sleep apnoea in the analysed patients was positively correlated with the duration and severity of TMD.

2. Most patients did not link the symptoms of sleep apnoea with dysfunctions of the stomatognathic system.

\section{References}

1. De Boever J.A., Adriaens P.A.: Occlusal relationship in patients with pain-dysfunction symptoms in the temporomandibular joints. J Oral Rehabil. 1983, 10, 17.

2. Helkimo M.: Studies on function and dysfunction of the masticatory system. II. Index for anamnestic and clinical dysfunction and occlusal state. Swed Dent J. 1974, 67, 2, 101-121.

3. Marbach J.J.: The temporomandibular pain dys-function syndrome personality: fact or fiction? J Oral Rehabil. 1992, 19, 545-560.

4. Michelotti A., Cioffi I., Festa P., Scala G., Farella M.: Oral parafunctions as risk factors for diagnostic TMD subgroups. J Oral Rehabil. 2010, 37, 3, 157-162.

5. Miller V.J., Karic V.V., Myers S.L., Exner H.V.: The temporomandibular opening index (TOI) in patients with closed lock and a control group with no temporomandibular disorders (TDM): an initial study. J Oral Rehabil. 2000, 27, 815-816.

6. Okeson J.P.: Occlusion and functional disorders of the masticatory system. Dent Clin North Am. 1995, 39, 285-300.

7. Okeson J.P.: Management of temporomandibular disorders and occlusion. Elsevier Mosby, Philadelphia 2003, 100-130.

8. Panek H.: Holistic concept of the stomatognathic system. Dent Med Probl. 2004, 41 (2), 277-280.

9. Schmitter M., Rammelsberg P., Hassel A.: The prevalence of signs and symptomsof temporomandibular disorders in very old subjects. J Oral Rehabil. 2005, 32, 467-473.

10. Skrzypkowski A.: On necessity of periodic examination of stomatognatic apparatus in flying personnel. Pol Prz Med Psychol Lot. 2011, 2, 17.

11. Stein S., Hart D.L., Loft G., Davis H.: Symptoms of TMJ dysfunction as related to stress measured by the social readjustment rating scale. J Prosthet Dent. 1982, 47, 5, 545-548.

12. Tallents R.H., Macher D.J., Kyrkanides S., Katzberg R.W., Moss M.E.: Prevalence of missing posterior teeth and intraarticulartemporomandibular disorders. J Prosthet Dent. 2002, 87, 45.

13. Witter D.J., Creugers N.H.J., Kreulen C.M., Haan A.F.J.: Occlusal stability in shortened dental arches. J Dent Res. 2001, 80, 432.

14. van der Meulen M.J., Lobbezoo F., Aartman I.H., Naeije M.: Self-reported oral parafunctions and pain intensity in temporomandibular disorder patients. J Orofac Pain. 2006, 20, 1, 31-35.

15. Zieliński J., Plywaczewski R., Bednarek M.: Zaburzenia oddychania w czasie snu. Wyd. Lek. PZWL, Warszawa 2006.

16. Wysocki J., Prus M., Balcerzak M.: Obstructive sleep apnea as interdyscyplinary medical problem. Pol Prz Otolaryngolol 2014, 31, 27-30.

17. Szymańska J., Dobrowolska-Zarzycka M.: Symptoms, complications and teatment of obstructive sleep apnea . Med Og Nauki Zdr. 2013, 19, 4, 391-396.

18. Tomasik M.: The role of the dentist in the diagnosis and treatment of snoring and sleep apnoea. Mag Stom. 2014, R 9, 108-112. 